\title{
71. On the Seasonal Changes of the Leptomedusa, Eucheilota paradoxica
}

\author{
By Tohru UchIDA*) and Yasuo SugIUrA**) \\ (Comm. by Sajiro Makıno, M. J. A., May 9, 1975)
}

The juvenile medusa just liberated from the mother body (Fig. A) is about $0.6 \mathrm{~mm}$ wide and $0.5 \mathrm{~mm}$ high in living state. Umbrella somewhat flatter than a hemisphere. Conspicuous spindle shaped nematocysts are scattered all the surface of umbrella. Radial canals four in number. There are two developed opposite perradial tentacles elongated from the bulbs and two developed perradial bulbs without tentacles. The tentacles are tapering and the length is about as long as the umbrella diameter. Cirri developing on either side of the perradial tentacle bulbs. The interradial marginal cirri are found only in medusae just liberated and disappear within two or three days after liberation. These marginal cirri are afterwards replaced by interradial tentacle bulbs. Statocysts are two in a pair located close to the perradial tentacle bulbs. Velum well developed. Manubrium four sided and tubular but not so long. From the base of manubrium, cross shaped rudiments of medusa bud and gonad arise along the radial canals. Tentacle bulbs and the base of manubrium are slightly brownish green in living state. Medusae just liberated rapidly grow at the beginning step. For instance, the medusa showing $0.6 \mathrm{~mm}$ in width and $0.5 \mathrm{~mm}$ in height became $0.9-1.1 \mathrm{~mm}$ and $0.7-0.8 \mathrm{~mm}$ respectively in living state after three days under the constant water temperature of $20^{\circ} \mathrm{C}$ (Figs. B, J).

Morphological changes from just liberated medusa to the adult are shown as follows. Umbrellar nematocysts almost disappear in early stage of medusa. From the non-tentacular bulbs, one pair tentacles develop. From the side of interradial bulbs finger-shaped cirri begin to appear. Cirri in a pair are not synchronously appear. Therefore, there can be seen mostly only one cirrus in one side or one cirrus longer than the other. Statocysts shift close to adradial axis on umbrellar margin. Tubular manubrium oblong downward.

As to the adult medusa will be described as follows*) (Figs. C, $\mathrm{D}, \mathrm{E}, \mathrm{F}, \mathrm{K})$. Umbrella $0.8-2.2 \mathrm{~mm}$ (1.2 mm mean) wide and 0.5-

*) Biological Laboratory, Imperial Household, Chiyoda-ku, Tokyo.

**) Laboratory of Biology, Dokkyo University, Soka-shi, Saitama-Ken.

1) Measured values following described are shown by fixed state of medusae but those of figures are all in living state. 


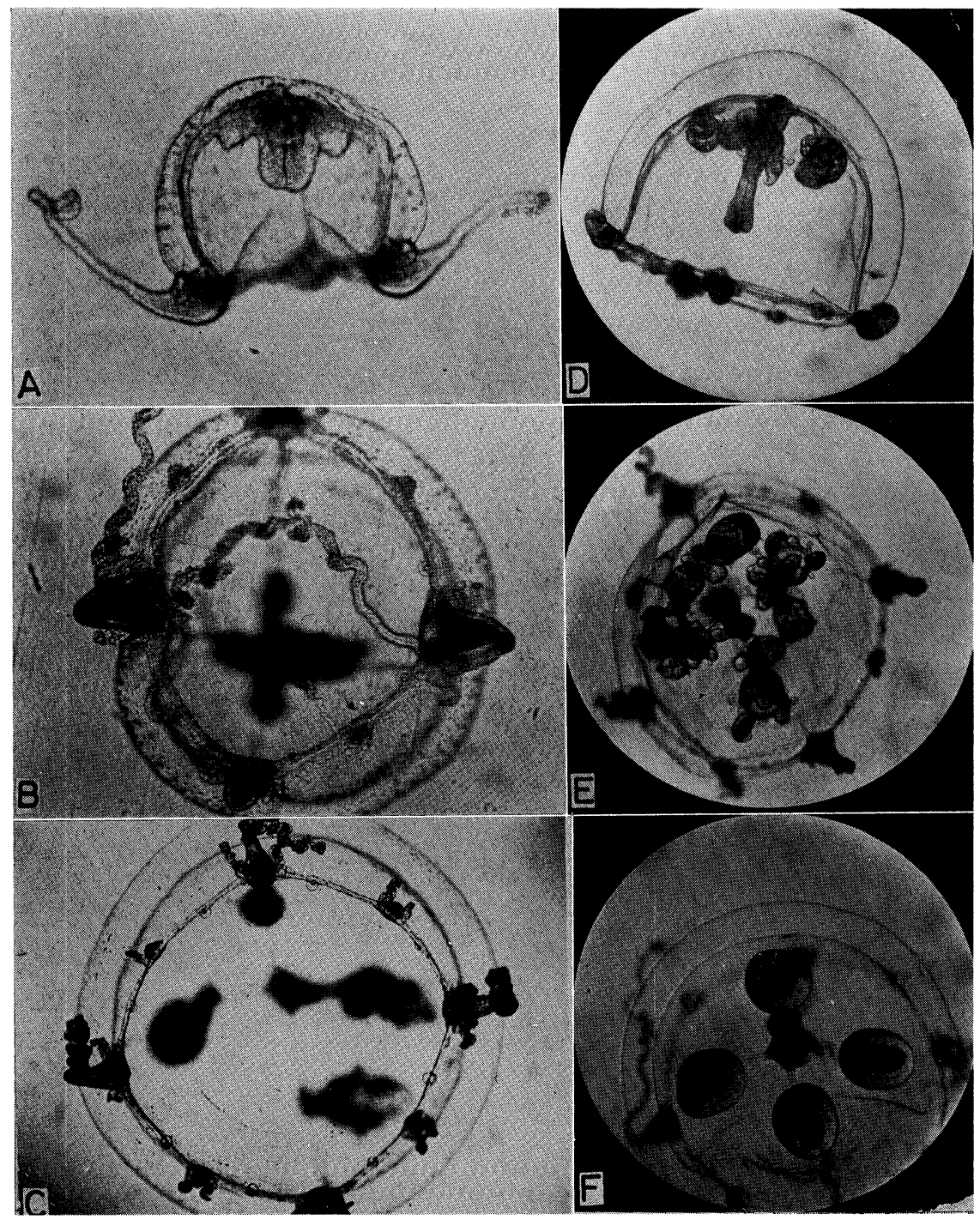

Figs. A-F. A: Newly liberated medusa, $0.6 \mathrm{~mm}$ wide $0.5 \mathrm{~mm}$ high, side view, only one pair of tentacles developing, manubrium encircled by four rudiments of medusa bud and gonad, with umbrella nematocysts clearly seen. B: Juvenile medusa 3 days after liberation, $0.9 \mathrm{~mm}$ wide $0.7 \mathrm{~mm}$ high, only one interradial marginal cirrus remains. C: Adult medusa, $1.8 \mathrm{~mm}$ wide, perradial tentacle bulbs develop with coiled tentacles, cirri in a pair developing not synchronously. D: A medusa with buds, $1.0 \mathrm{~mm}$ wide, buds hanging down at upper corners of subumbrellar cavity. E: A medusa with large number of buds, $1.1 \mathrm{~mm}$ wide, including all the stages except V. F: Upper part of umbrella showing ripe testes, $1.0 \mathrm{~mm}$ wide, 


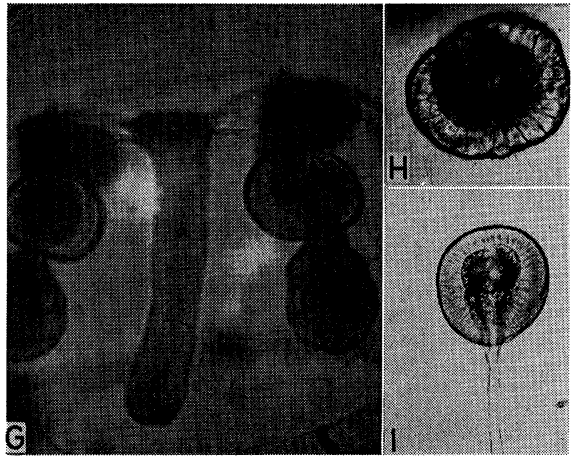

Figs. G-I. G: Side view of testes accompanied each with a medusa buds, $1.8 \mathrm{~mm}$ wide, tube-like manubrium hanging down from the upper central part of subumbrellar cavity. $\mathrm{H}$ and I: Enlarged views of the ovary and testis attached to radial canal.

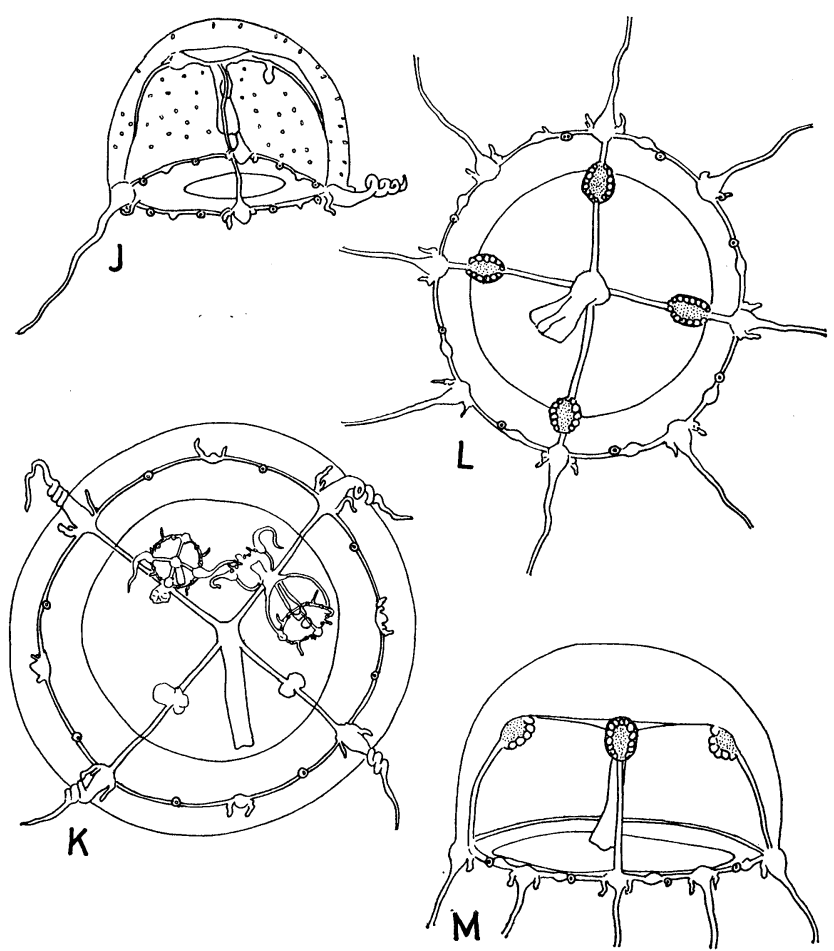

Figs. J-M. J: Juvenile medusa 3 days after liberation, $1.1 \mathrm{~mm}$ wide $0.8 \mathrm{~mm}$ high. $\mathrm{K}$ : Aduld medusa, $1.8 \mathrm{~mm}$ wide, having well developed medusa buds of Stage V. L and M: Extremely well developed medusa, $2.9 \mathrm{~mm}$ wide, with interradial marginal tentacles; eight adradial bulbs. 

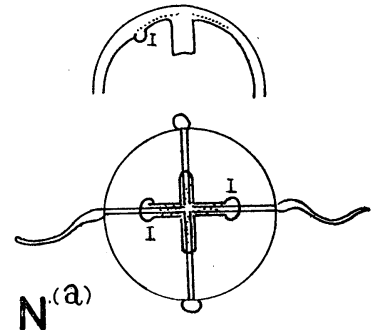

$N^{(a)}$

Fig. N: Schematic figures showing the development of medusa bud mass, arabic numerals showing each developmental stage of buds; dotted area denotes common rudiments of medusa bud and gonad on radial canals.

$1.7 \mathrm{~mm}$ ( $0.9 \mathrm{~mm}$ mean) high. Jelly of umbrella moderatly develops. Four radial canals are jointed to ring canal which is passing through along the umbrellar margin. Tentacle bulbs belonging to the perradial axis are well developed with one or two pairs of cirri on either side of them. From the four perradial bulbs arise a tentacle respectively. On the contrary, interradial bulbs are not so developed compared with the perradial ones and they usually have one or two pairs of cirri. Tentacles are usually found only on the perradial bulbs and interradial bulbs have generally no tentacles, but present in an extremely well developed medusa (Figs. L, M). Tentacles are usually coiled, sometimes elongated two or three times of umbrellar diameter. The tentacles have no terminal knob. Eight statocysts, each with one statolith, exceptionally two, are adradially located on the umbrellar margin. Velum well developed. Manubrium tube-like and prolonged, its tip terminated with four lips which do not well develop.

Whenever the medusae are collected, budding of medusa can be seen in their bodies. Buds are formed on the common locality of rudiment of medusa bud and gonad. The rudiment is already recognized in young medusa before liberation (Fig. A). In such a juvenile medusa, the rudiment is connected with the base of manubrium and prolonged itself along the radial canals. With the growth of medusa, the rudiment shifts from the manubrium and eventually locates to upper corners of subumbrellar cavity along the radial canals. The rudiments are the cell mass which is ellipsoidal in shape. The buds grow on the under side of each rudiment. It is convenient to classify the morphological changes of a buds according to the degree of development as follows (Figs. D, E, N) :

Stage I: Medusa budding begins as a small tubercular process of a finger-like shape from the rudiment. 
Stage II: The process becomes enlarged and formation of medusa nucleus begins.

Stage III: Juvenile medusa, especially tentacles, manubrium and so on begin to be formed within the thin membrane.

Stage IV: A pair of tentacles, a pair of tentacle bulbs and four interradial cirri are exposed from the umbrella. The proximal portion of a pair of tentacles become extremely wide and become extraordinally thin making curve in terminal portion, forming often bird bill-like shape. On the other hand, also a pair of bulbs without tentacle well developed and bulged out. Between the tentacle and tentacle bulb coiled cirri appear.

Stage V: The medusa just before liberation is morphologically almost same as the just liberated (Figs. A, K).

Next will be described the development of the medusa bud groups as mass derived from the rudiments. In the case of the medusa newly liberated, buds begin to grow in the terminal portion of the cross-shaped rudiments (Fig. J). In the medusa just liberated, buds adjacent to the tentacle axis are apt to be earlier formed than that of non tentacle axis (Fig. N-a). With the growth of medusa, the rudiments shift from the base of manubrium and medusa budding proceeds as follows. When the first bud somewhat enlarged, the following buds begin to develop. The following buds usually arise from at first the centripetal portion of the rudiment and on the left or right side, sometimes both sides of the radial canal (Fig. $\mathrm{N}-\mathrm{b}$ ). When the budding begin to occur, the medusa is about 0.7$0.8 \mathrm{~mm}$ wide and $0.6-0.7 \mathrm{~mm}$ high. As the growth patterns of bud groups are various, it is very difficult to find the general order of bud group formation. The buds successively formed also seem to arise from the centripetal side of the rudiment (Fig. N-c). Numbers of bud found in one medusa were 10 in the mean and range $0-31$, especially individuals with 6-11 buds amount to $60 \%$. Individual with 31 buds may be the exceptional example having the largest number of buds, in which buds arise mostly in the rudiments with only 3 buds in the base of manubrium. Medusae with buds hanging down from the ripe gonad were observed. In these cases, 2 in the mean and they ranges $0-8$, including individuals, without buds amount $35 \%$.

The rudiments of medusa bud are also that of gonad. Sexually mature medusae are usually found in later period of the season of medusan appearance. The medusae which are sexually immature are $0.8-2.0 \mathrm{~mm}$ (1.2 mm mean) wide and $0.5-1.5 \mathrm{~mm}$ (0.9 mm mean) high in size. On the other hand, mature female are $0.8-1.6 \mathrm{~mm}$ (1.1 mm mean) wide and $0.5-1.0 \mathrm{~mm}(0.8 \mathrm{~mm}$ mean $)$ high, while 
Table I. The dates and the water temperatures at the time of Eucheilota paradoxica occurrence and disappearance of the year

\begin{tabular}{c|crll}
\hline & \multicolumn{4}{|c}{ Date (water temperature) } \\
\cline { 2 - 4 } & \multicolumn{2}{|c}{ Appearance } & \multicolumn{2}{c}{ Disappearance } \\
\cline { 2 - 4 } 1970 & July & $11\left(21.2^{\circ} \mathrm{C}\right)$ & September & $26\left(22.4^{\circ} \mathrm{C}\right)$ \\
1971 & July & $4\left(23.8^{\circ} \mathrm{C}\right)$ & October & $24\left(20.5^{\circ} \mathrm{C}\right)$ \\
1972 & May & $7\left(17.8^{\circ} \mathrm{C}\right)$ & September & $10\left(26.0^{\circ} \mathrm{C}\right)$ \\
1973 & April & $30\left(18.0^{\circ} \mathrm{C}\right)$ & October & $26\left(19.9^{\circ} \mathrm{C}\right)$ \\
1974 & April & $2\left(15.3^{\circ} \mathrm{C}\right)$ & September & $22\left(22.2^{\circ} \mathrm{C}\right)$ \\
1975 & March & $2\left(14.2^{\circ} \mathrm{C}\right)$ & & \\
\hline
\end{tabular}

mature males are $0.8-2.2 \mathrm{~mm}(1.2 \mathrm{~mm}$ mean $)$ wide and $0.7-1.7 \mathrm{~mm}$ $(0.9 \mathrm{~mm}$ mean $)$ high. It is fairly difficult to find the differences between immature and mature medusae from sizes and as also shapes. The ovary and testis are formed at the upper corners of subumbrellar cavity on the radial canals and are round or slightly ellipsoidal in shape and their diameters in long axis are 1/4-1/6 of the umbrellar diameter (Figs. F, G, H, I).

The collection of surface plankton have been continued since April of 1970 till March of 1975 once a week at Misaki, Kanagawa Prefecture. The days and the water temperatures at the time of the medusan occurrence and disappearance are shown in Table I. Three or four times a year, extremely amount of the medusae were captured in one tow. The water temperatures at the times were ranged between $18.6^{\circ} \mathrm{C}$ and $27.0^{\circ} \mathrm{C}$ and in most cases were over $22^{\circ} \mathrm{C}$. Such a phenomenon indicates the rapid activity of multiplication due to asexual reproduction, caused by the higher temperature. On the other hand, also the sexual reproduction is carried out in later period of the season of the medusan occurrence as shown in Table II.

Table II. The dates when sexually mature Eucheilota paradoxica were found, with the water temperatures at the time of the year

\begin{tabular}{l|l}
\hline & \multicolumn{1}{|c}{ Date (water temperature) } \\
\hline 1970 & Aug. $22\left(24.9^{\circ} \mathrm{C}\right)$, Aug. $29\left(25.2^{\circ} \mathrm{C}\right)$ \\
1971 & Aug. $1\left(26.6^{\circ} \mathrm{C}\right)$, Oct. $12\left(19.5^{\circ} \mathrm{C}\right)$ \\
1972 & Aug. $24\left(22.7^{\circ} \mathrm{C}\right)$, Sept. $3\left(24.0^{\circ} \mathrm{C}\right)$, Sept. $10\left(26.0^{\circ} \mathrm{C}\right)$ \\
1973 & Sept. $17\left(22.2^{\circ} \mathrm{C}\right)$, Sept. $26\left(23.5^{\circ} \mathrm{C}\right)$, Sept. $30\left(22.2^{\circ} \mathrm{C}\right)$, Oct. $5\left(22.5^{\circ} \mathrm{C}\right)$ \\
1974 & June $30\left(22.0^{\circ} \mathrm{C}\right)$, Sept. $9\left(25.8^{\circ} \mathrm{C}\right)$, Sept. $12\left(25.0^{\circ} \mathrm{C}\right)$ \\
\hline
\end{tabular}

